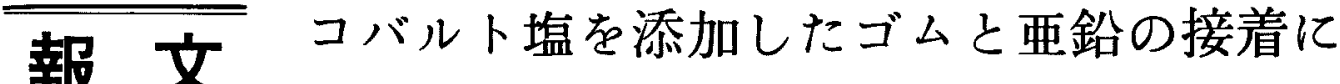 おける加硫促進剤の影響
}

(昭和57年 9 月 10 日 受理)

\section{芦田道夫 ${ }^{*} \cdot$ 中谷雅也 ${ }^{*} \cdot$ 竹本好孝* . 後藤万龟雄 ${ }^{*}$}

\begin{abstract}
要 旨 ナフテン酸コバルト又はステアリン酸コバルトを添加したNR と亜鉛との接着における加硫促進

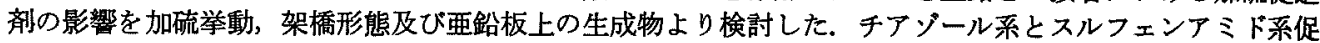
進剤ではコバルト塩添加による加硫速度への影響は小さく，最高の接着力を生じて破断面はゴム層破壊であ った. しかし $160^{\circ} \mathrm{C}$ 加硫ではポリスルフィド架橋数が減少し，モノスルフィド架橋数が増し，接着力は時 間とともに急速に低下して界面はく離に変った。CBS は MBT よりこの接着力低下を促進した。 ナフテン 酸コバルトの添加はステアリン酸コバルトの添加より大きい接着力を生じ，一方高温での接着力低下を一層 促進した. チウラム系とジチオカルバミン酸塩系促進剤はコバルト塩と反応して促進作用を失ない，過㮃の コバルト塩の弱い促進効果により架橋を生じた.この系の見かけの接着力は硫黄量増加とともに増大した. DPG による加硫ゴムは重鉛板と接着しなかった，接着良好な亜鉛表面怡酸化亜鉛，硫化亜鈶，硫酸重 鉛か ら構成され，高温で接着力の低下した亜鉛面は酸化亜鉛と硫化亜鉛で構成されていた.
\end{abstract}

\section{1. 緒言}

ゴムと黄銅の接着におけるゴム配合剤の影響について は多くの研究があり, 加硫促進剂の種 類 ${ }^{1 \sim 3}$, 酸化要 鉛 $^{(4) 5) ， カ ー ホ ゙ ン フ ゙ ラ ッ ク ~}{ }^{6)}$ ，ステアリン酸》) などの接着 への影響が報告されている。一般にゴムと黄銅との接着 では加硫促進㓮として，スルフェンアミド系やチアゾー ル系を用いた加硫ゴムが接着強度大きく，グアニジン系 とチウラム系による加硫ゴムが接着不良であることが見 い出されており，これは接着がゴムの硫黄架橋と銅表面 の硫化物形成の競合区応と考えられ，スコーチ時間が長 いほど接着反応に良い効果を与えるとみられている ${ }^{8}$.

ゴムと亜鉛の場合は通常のゴム配合では加硫により接 着しない. しかしゴムにコバルト塩を添加して圧着加硫 すると強い接着力を生じる ${ }^{8)}$ 著者ら ${ }^{10}$ は NR と亜鉛の 接着で数種のコバルト塩を用い，ナフテン酸コバルトの 添加が最大の接着力を与え，加硫によりコパルトと硫黄 が覀鉛板上に移行することを報告した．また，ナフテン 酸コバルトを添加したスクアレンによる加硫のモデル実

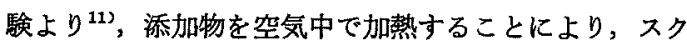
アレンへのナフテン酸コパルト付加化合物が形成される

†本報を〔ゴムと亜鉛の接着に関する研究(第 3 報)】 とする。

* 神戸大学工学部工業化学科 (テ657 神戸市灘区六甲 台町）

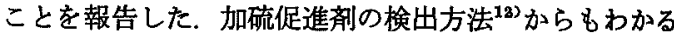
よらにコバルト塩は加硫促進倣と反応して錯体を形成す ることが予想される.Rutz ${ }^{183}$ は NBR や NR と黄銅との 接着にステアリン酸コバルトを添加して，加硫促進剤及 び老化防止昘の種類による加硫への影響について調へ， チウラム系促進威はコパルト塩と錯体を形成して促進作 用が低下することを報告している，したがってゴムと亜 鉛の接着では加硫促進剤の効果は黄銅の場合と異なって くるものと思われる．本研究ではナフテン酸コバルトま たはステアリン酸コバルトを添加した NR と要鉛板の 接着において，加硫促進剤によるゴムの加硫挙動及び接 着力への影響について求め，両者の相関関係について検 討した。

\section{2. 実 験 方 法}

\section{1 試 料}

天然ゴム(RSS\#1)にカーボンブラック(シースト3)及 び各種配合剂を Table 1 に示す割合で加え，3インチ試

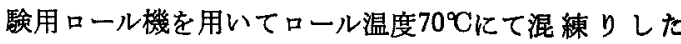
後, 厚さ $2.0 \mathrm{~mm}$ のシートに成形した. ナフテン酸コバ ルトは流動パラフィンに混合し，窒素雾囲気で $80^{\circ} \mathrm{C}$ に加 熱して均一な溶液として添加した. ステアリン酸コバル トはりん片状粉末をそのまま添加した。

接着用亜雓板には純度 $99.6 \%$ ，厚さ $1 \mathrm{~mm}$ の亜鉛板を $2 \times 6 \mathrm{~cm}$ の短冊形に切断して用い，㭬磨機にて研摩紙 
Table 1 Recipe

(phr)

\begin{tabular}{|c|c|c|c|}
\hline NR (RSS \#1) & 100 & 100 & 100 \\
\hline Carbon black (Seast) & 40 & 40 & 40 \\
\hline Zinc oxide & 5 & 5 & 5 \\
\hline Sulfur & 2.5 & $2.5-7.5$ & 5.0 \\
\hline Stearic acid & 1 & 1 & 1 \\
\hline Accelerator* & 1 & 1 & 1 \\
\hline $\begin{array}{l}\text { Cobalt naphthenate } \\
\text { (Co content: } 10 \% \text { ) }\end{array}$ & & 6 & \\
\hline $\begin{array}{l}\text { Cobalt Stearare (Co } \\
\text { content: } 10 \% \text { ) }\end{array}$ & & 6 & \\
\hline Liquid paraffine & & 3 & \\
\hline
\end{tabular}

*Accelerator; CBS (n-cyclohexyl benzothiazole sulfenamide), MBT (2-mercapto benzothiazole), MBTS (dibenzothiazyldisulfide), ZnMBT (zinc salt of 2-mercaptobenzole), DPG (diphenyl guanidine), ZnMDC (zinc dimethyldithiocarbamate), NaMDC (sodium dimethyldithiocarbamate), TMTD (tetramethylthiuramdisulf ide)

\#1000とアルミナ馝濁液で研磨し鏡面仕上げにした後, ア セトン洗涤して乾燥後直ちに用いた.

\section{2 加硫試験}

配合末加硫ゴムの約 $4.5 \mathrm{~g}$ をキラストメーター(JSR 一I型)を用いてダイス\#1 (2 mm), オッシレーティンダ 角度 $\pm 3^{\circ}$ にて一定温度での加硫曲線を測定し，式(1)よ り加硫速度を求めた。

$$
R=\frac{F_{80}-F_{10}}{T_{90}-T_{10}}
$$

ここで $F_{90}=\left(F_{\max }-F_{\min }\right) 90 / 100+F_{\min }, F_{10}=\left(F_{\max }-\right.$ $\left.F_{\text {min }}\right) 10 / 100+F_{\min }, F_{\max }$ は最高卜ルク值, $F_{\min }$ は最低卜 ルク值, $T_{10}$ は測定開始時から $F_{10}$ に達するまでの時間, $T_{90}$ は測定開始時から $F_{90}$ に達するまでの時間である.

\section{3 接着試験}

厚さ $2 \mathrm{~mm}$ の未加硫ゴムシートと亜鉛板の閒に $1 \mathrm{~cm}$ 角の穴をあけたポリエステルフィルムを挟み，一定温度 でプレス加硫（圧力 $2.2 \mathrm{MPa}$ ) し，接触面積 $1 \mathrm{~cm}^{2} の コ ゙$ ムと亜鉛の接着面を作った. 一日放置後接着試料をオー トグラフ(島津 IM-100 型)を用い， $50 \mathrm{~mm} / \mathrm{min}$ の引張 速度で T型はく離試験を行って接着強度を求めた。

\section{4 硫黄架橋数の測定}

厚さ $1 \mathrm{~mm}$ の加硫ゴムシートを幅 $1.3 \mathrm{~mm}$ の短冊状 に切り試験片とし，Campbell ${ }^{14)}$ の方法により次のよう に処理して架橋を分解した. (1)試験片をへプタン中に入 れ空素骞囲気にて $25{ }^{\circ} \mathrm{C} て ゙ 24$ 時閒膨潤して遊離硫黄を除去 した後，(2)プロパン-2-チオール及びピペリジン混 合 液
中にてポリスルフィド架橋を分解した。(3試験片をへキ サン-1-チオールのピペリジン溶液中で窒素零囲気 で処 理し，ポリ及びジスルフィド架橋を分解した.このよう に処理した試験片の引張応力の測定から式(2)により網目 鎖灌度を求めた ${ }^{15}$.

$$
\sigma=\sigma_{0}+\nu \mathrm{RT}\left(\alpha-\frac{1}{\alpha^{2}}\right)
$$

ここで $\sigma$ は応力 $\left(\mathrm{MP}_{\mathrm{a}}\right), \sigma_{0}$ は定数，v は見かけ網目鎖濃 度 $\left(\mathrm{mol} / \mathrm{cm}^{3}\right), R$ は気体定数 $\left(\mathrm{Nm} /{ }^{\circ} \mathrm{C} \mathrm{mol}\right), \alpha$ は伸張比 である。

\section{5 亜鉛表面の化学分析}

接着試験後の亜鉛板を数日間ベンゼン中に漫せきして 付着ゴムを充分に膨閏させ，表面を傷つけないよらに樹 脂製へらでゴムを除き金属面を露出させた，その後アセ トン中で超音波洗條して ESCA で表面分析を行った.

\section{3. 結果と考察}

$\mathrm{MBT}$ 配合 NR にナフテン酸コバルトを添加したとき の加硫曲線は無添加のときとほとんど変らず, ナフテン 酸コバルトは MBT の加硫促進作用に影響を与えていな い. ZnMDC は超加硫促進肪であり，加硫曲線は Fig. 1のように加硫によりトルク值は急上昇し，最高トルク 值も非常に高いのに対し，ナフテン酸コバルトを添加す ると $140^{\circ} \mathrm{C}$ 加硫では30分後むトルク值は低く，まだ徐 々に上昇しており，ZnMDC の加硫促進作用が消隇した ことを示している，加硫温度が高くなると加硫速度は速 くなり最高トルク值を与えて加硫戻りを生しる.しか し，その最高トルク值はコバルト塩未添加の場合のトル ク値に比べ非常に小さい. Fig. 2 は ZnMDC 1 phr (ニ $3.3 \times 10^{-3}$ モル)配合 NR のナフテン酸コバルト添 加量

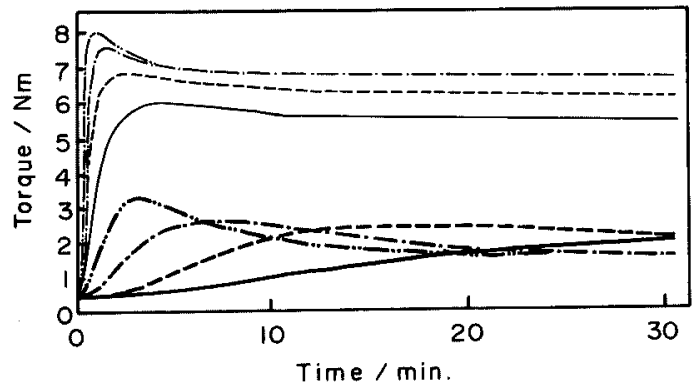

Fig. 1 Curing curves of NR compounds with ZnMDC (fine lines) and with $\mathrm{ZnMDC}$ and cobalt naphthenate (bold lines) at temperatures of $140^{\circ} \mathrm{C}$ $(\longrightarrow), 150^{\circ} \mathrm{C}(--), 160^{\circ} \mathrm{C}(-\cdot-)$, and $170^{\circ} \mathrm{C}$ $(-\cdots-)$. 


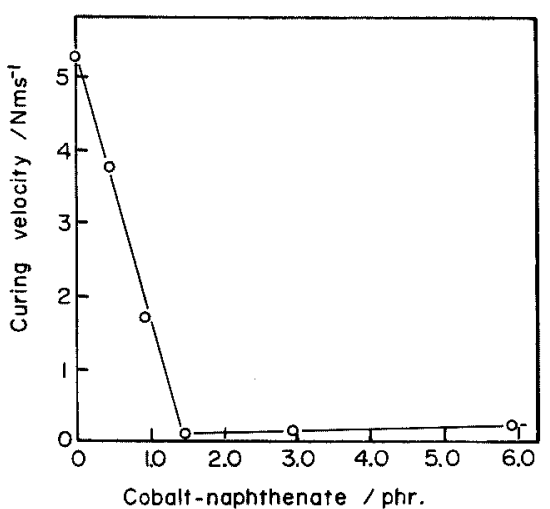

Fig. 2 Relationship between curing velocity and cobalt naphthenate dosage of NR compounds accelerated with ZnMDC 1 phr.

と加硫速度との関係を示した. ナフテン酸コバルト量の 増加に伴って加硫速度は直線的に減少し, $1.5 \mathrm{phr}$ (コバ ルト 2. $6 \times 10^{-3}$ モル) 添加により反応速度はほぼ 0 と なり，更に添加量増すと反応速度は僅加に上昇してき た. したがって ZnMDC はコバルトの等モルと反応し て加硫促進の活性を失なったとみられる.

Table 2 は各種の加硫促進剤配合 NR にナフテン酸コ バルトを添加した場合の $150^{\circ} \mathrm{C}$ 亿おける加硫特性である。 チアゾール系とスルフェンアミド系促進剤は無添加のと きと同じ，あるいはそれ以上の加硫促進作用がみられ， MBT と同様にナフテン酸コパルトの影響は小さかっ た. グアニジン采促進㓮では促進效果は低下し，最高卜 ルク值は小さくなり加硫戻りは増大した. ジチオカルパ ミン酸塩系とチウラム系促進剂は ZnMDC と同様にナ フテン酸コバルトと反応して促進作用を消失した。

ZnMDC のベンゼン溶液はナフテン酸コバルトと次の ように反応して黄緑色を呈する。

$\left[\begin{array}{l}\mathrm{CH}_{3} \\ \mathrm{CH}_{3}\end{array} \stackrel{\stackrel{\mathrm{N}}{\mathrm{N}}-\mathrm{C}}{\mathrm{C}}\right]_{2} \mathrm{Zn}+\mathrm{Co}^{2+} \rightarrow\left[\begin{array}{l}\mathrm{CH}_{3} \\ \mathrm{CH}_{3}\end{array}>\mathrm{N}-\stackrel{\mathrm{S}}{\mathrm{C}}\right]_{2} \mathrm{Co}+\mathrm{Zn}^{2+}$
ことより ZnMDC は加硫中にジメチルジチオカルパ ン酸コバルトを形成し加硫促進作用を失なったと考えら れる。 また TMTD は加硫中に酸化覀鉛と反応して中間 体を形成し，この中間体が ZnMDC に変わると同時に 架橋を形成する

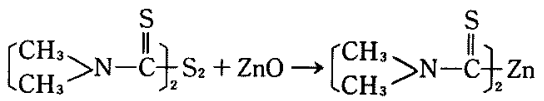

とみられており，添加ナフテン酸コパルトは式(4)の酸化 亜鉛に代り TMTD と直接反応してコバルト塩を形成す ると考えられる．一方 MBT のクロロホルム溶液はナフ テン酸コバルトのベンゼン溶液と次のよ5に反応して青 緑色を呈する

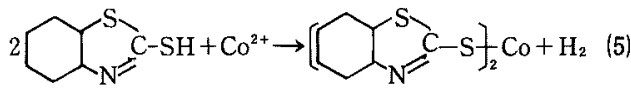

したがって MBT も加硫中に2-メルカプトベンゾチアソ ールのコバルト塩を形成することが考えられる。しかし このコバルト塩は带鉛塩と同様に分解して加硫促進勃果 を与えるのであろう。

ステアリン酸コパルトを添加した場合の促進剤による 加硫挙動は，ナフテン酸コバルト添加の場合に比べ最高 トルク值は小さいが類似しており，促進剂とは同様な反 応を生ずとる思われる。

Fig. 3 はナフテン酸コバルトを添加した MBT 加硫 ヨ゙ムの配合硫黄量による加硫速度への影響を示した．加 硫温度 $150^{\circ} \mathrm{C}$ では硫黄量の増加とともにスコーチ時間は 短かく，加硫速度は速くなり，最高トルク值も増大乙 た.一方，170Cではスコーチ時間は一層短かくなり，卜 ルク值は急速な上昇により最高值に達した後大きく減少 し,硫黄量が増すとこの傾向は更に強められた. このよう なトルク值の加硫時間による変化はナフテン酸コバルト 無添加のときとほぼ同様であるが，高温になると劣化が 一層促進されている. ZnMDC 加硫ゴムの硫黄量による 加硫速度の変化を Fig. 4 に示した.すでに述べたように ナフテン酸コバルトを添加すると, ZnMDC の促進作用

Table 2 Vulcanization characteristics of NR compounds with cobalt naphthenate at curing temperature of $150^{\circ} \mathrm{C}$

\begin{tabular}{lrrrrrrrr}
\hline Accelerator & MBT & MBTS & ZnMBT & CBS & DPG & ZnMDC & NaMDC & TMTD \\
\hline$F_{\min }(\mathrm{Nm})$ & 0.265 & 0.248 & 0.262 & 0.276 & 0.386 & 0.332 & 0.403 & 0.413 \\
$\mathrm{~F}_{\max }(\mathrm{Nm})$ & 3.83 & 4.00 & 3.72 & 4.48 & 3.34 & 2.35 & 2.23 & 2.36 \\
$\mathrm{~F}_{30}(\mathrm{Nm})$ & 3.78 & 4.00 & 3.58 & 4.11 & 2.51 & 2.22 & 1.86 & 2.36 \\
$\mathrm{R} \times 10(\mathrm{Nm} / \mathrm{min})$ & 5.21 & 4.41 & 4.42 & 13.7 & 4.60 & 1.51 & 1.89 & 0.96 \\
\hline
\end{tabular}

Fmin; minimum torque, $\mathrm{Fmax}_{\mathrm{x}} ;$ maximum torque, $\mathrm{F}_{30}$; torque after $30 \mathrm{~min} . \mathrm{R}$; vulcanization velocity 


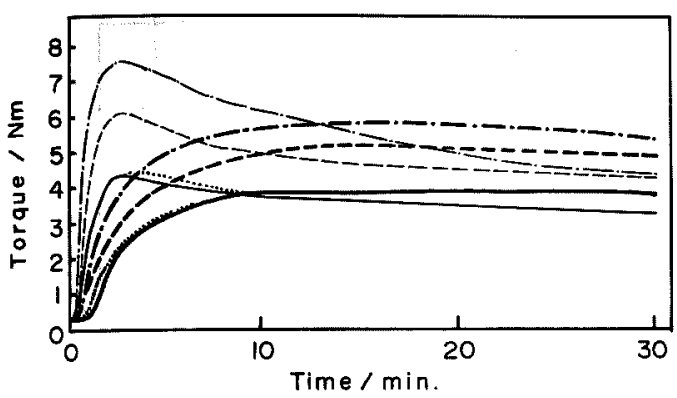

Fig. 3 Influence of sulfur dosage and cure temperature on curing curves of NR compounds with MBT and cobalt naphthenate at $150^{\circ} \mathrm{C}$ (bold lines) and $170^{\circ} \mathrm{C}$ (fine lines). The sulfur dosage are $2.5 \mathrm{phr}$ (-), $5.0 \mathrm{phr}(--)$, and $7.5 \mathrm{phr}$ (- - ). Dotted lines are those of NR compound without cobalt salt.

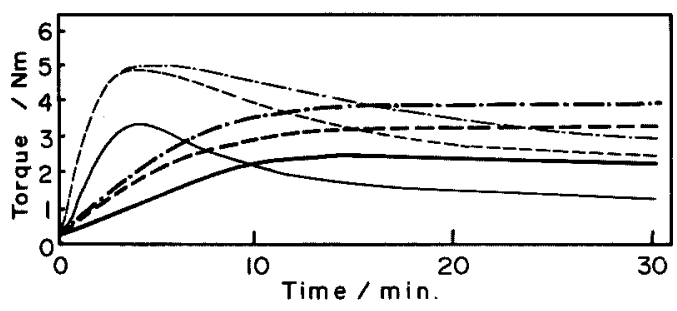

Fig. 4 Influence of sulfur dosage and cure temperature on curing curves of NR compounds with $\mathrm{ZnMDC}$ and cobalt naphthenate at $150^{\circ} \mathrm{C}$ (bold lines) and $170^{\circ} \mathrm{C}$ (fine lines). The sulfur dosage are $2.5 \mathrm{phr}(-), 5.0 \mathrm{phr}(--)$, and $7.5 \mathrm{phr}$ $(-\cdot-)$.

は消失して加硫速度は非常に遈くなるが，硫黄量が増す とともに速度は徐々に上昇し最高トルク值も增大した。

$7.5 \mathrm{phr}$ ではトルク值はコバルト塩末添加の場合の值近 くまで増した. TMTDや NaMDC 加硫の場合も硫黄量 の増加により加硫速度は同様の上昇を示した，また加硫 促進剤を加えずナフテン酸コバルトのみを添加した NR の加硫曲線も硫黄量により同じ傾向の変化であった. し たがってカルバミン酸塩系とチウラム系促進剂添加の 場合は，これら促進剂はナフテン酸コバルトと反応して 促進作用を失ない，過剩のナフテン酸コバルトによる加 硫促進効果が硫黄量増加と温度上昇により現われてきた のであろ5.

ゴムと亜鉛板の T 型はく離法による破壊には，(1)ゴ ムー监鉛間に結合がなく金属面を露出する界面はく離,

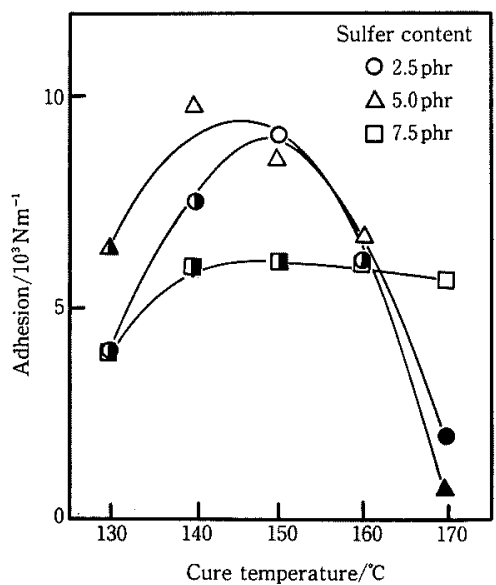

Fig. 5 Effect of cure temperature and sulfur dosage on adhesion of NR compounds with MBT and cobalt naphthenate. White signs show rubber breakage, half black ones interface breakage and black ones interface peel.

(2)ゴム-亜鉛間結合の破壊による界面破壊，(3)ゴムー眔鉛 間の結合力がゴム分子間の結合力より大きく，引張りに よりゴム層が切断されるゴム破断とがあり，第 3 の場合 に得られる芫かけの接着強度はゴムの強度であり真の接 着力はより以上であることを意味している ( $\mathrm{T}$ 型はく離 では応力がゴム接着面の一辺に局部的に集中して破壊が 生じるので引裂強度の一種とみなせる)。そこではく離 の亜鉛面を観察してこの3 種類に大別した. Fig. 5 は MBT 配合ゴムの加硫温度と接着強度との関係である.

硫黄量 $2.5 \mathrm{phr}$ では $150^{\circ} \mathrm{C} て ゙$ 最大強度を与えゴム層破壊

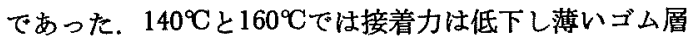

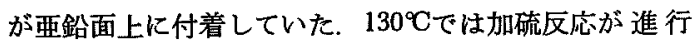
せず架橋不充分なため弱い忘力でゴムが切断された。 し かし亜鉛板上にはゴムが付着しており接着反応は生じて いるとみられる. $170^{\circ} \mathrm{C} て ゙ は$ 界面はく離となり接着力は著 しく低下した．硫黄量が増すとゴム層破壊の強い接着力

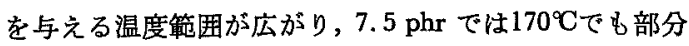
的にゴム破壊となりやや強い接着力を与え，硫黄量が少 ないほど接着力は加硫温度により大きく変動することが わかった. チアゾール系促進剤の接着力は MBTS> $\mathrm{MBT}>\mathrm{ZnMBT}$ の順であり，温度と硫黄量により同じ 影響を受けた.ZnMDC を配合した NR と亜鉛の接着 強度に及ぼす硫黄量と温度の影響を Fig. 6 に示した。 すでに述べたように促進剤は錯体を形成して加硫促進能 力を失ない，硫黄架橋が形成されないため，硫黄 量 2.5 


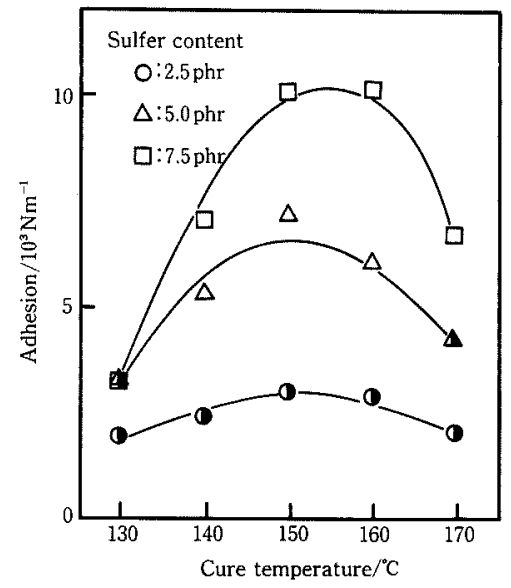

Fig. 6 Effect of cure temperature and sulfur dosage on adhesion of NR compounds with ZnMDC and cobalt naphthenate. White signs show rubber breakage, half black ones interface breakage and black ones interface peel.

$\mathrm{phr}$ のときは弱いカでゴム層が切断される．硫黄量を增 すと架橋数は増加してゴムの強度が增大し，その分見か けの接着力も増大している.TMTD や NaMDC も同し 㑯向を示し，チウラム系とジチオカルバミン酸塩系の接 着力はゴムの強度より大きいことは明らかである。した がって促進剤はコバルト㙁形成により加硫促進効果を消 失し，残りのナフテン酸コバルトによる加硫と接着の促 進作用が現われてきたのであろう。

Fig. 7 は硫黄を 5 phr 配合した CBS 加硫系の加硫時 間による接着強度の変化を示した. $150^{\circ} \mathrm{C}$ 以下では短時間 に最高強度に達し，時間が長くなると接着力は徐々に低 下してくる.この破壊状態はゴム層破断であり，加硫曲線 から明らかな上5に過加硫の状態であることから，ゴム の熱劣化による見かけの接着力低下であらう。一方，160 ${ }^{\circ} \mathrm{C}$ では10分間で最高強度に達し, その後急速に低下して 界面はく離となった。これはゴムの劣化により反応初期 にゴムと亜鉛間に生じた結合が時間が経つとともに開裂 したものとみられる.MBT 配合ゴムは Fig. 8 亿示した よ5に $150^{\circ} \mathrm{C}$ では接着強度は CBS のときと同じく加硫 時間とともに直線的に低下した. しかし， $160^{\circ} \mathrm{C}$ では 10 分間で最大接着強度に達し20分後でもまだかなりの接着 力を保持しておる゙，CBS に比べると高温での結合力の 低下が遅いことを示している. ZnMDC 配合ゴムの場合 は Fig. 9 に示したよらに，150Cではナフテン酸コバル トにより架橋反応が時間とともに進み見かけの接着強度

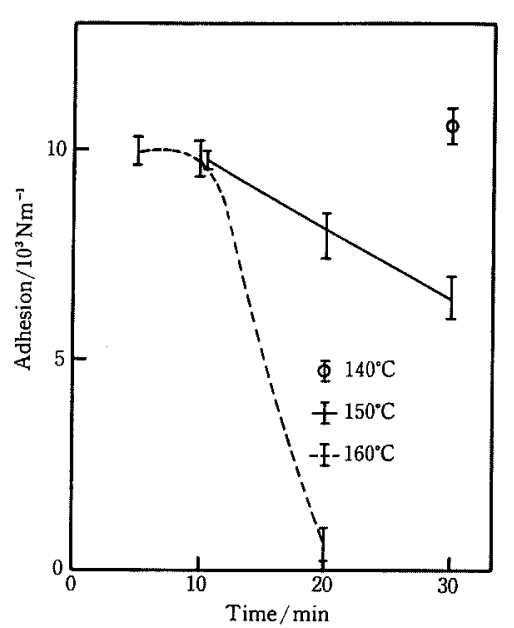

Fig. 7 Effect of cure time and temperature on adhesion of NR compounds with CBS and cobalt naphthenate.

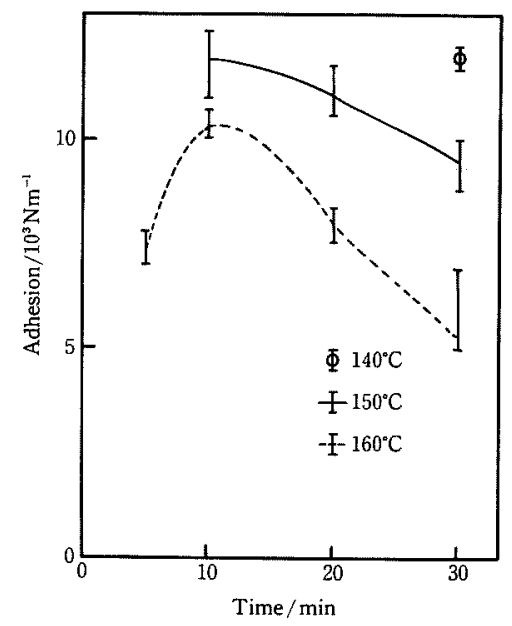

Fig. 8 Effect of cure time and temperature on adhesion of NR compounds with MBT and cobalt naphthenate.

は增大してきた. Fig. 10１2にはステアリン酸コバルト を添加した各加硫系の時間と接着強度の関係を示した。 ゴム層破断の接着強度がナフテン酸コバルト添加に比べ 低いのは，後述するように架橋数の少ないためであろう． この場合も $160^{\circ} \mathrm{C}$ に扔ける接着力は, CBS では時間とと もに急速に減少したのに対し MBT では徐々に低下し た. コバルト塩を添加した DPG 配合 NR は重鉛と接 着せず界面はく離であった，以上のよ5にコバルト㙁添 


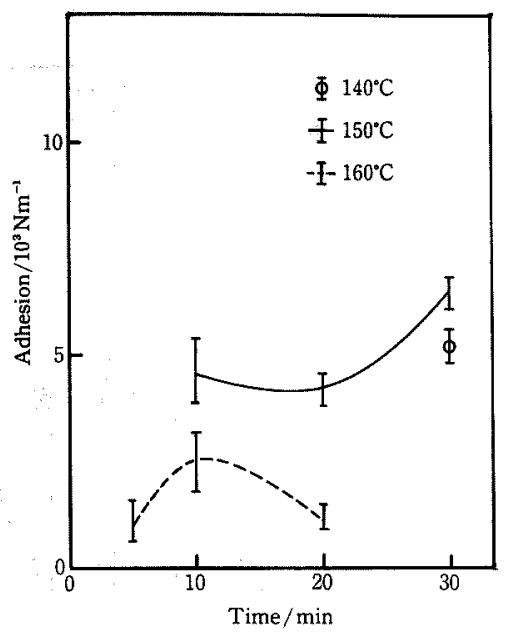

Fig. 9 Effect of cure time and temperature on adhesion of NR compounds with ZnMDC and cobalt naphthenate.

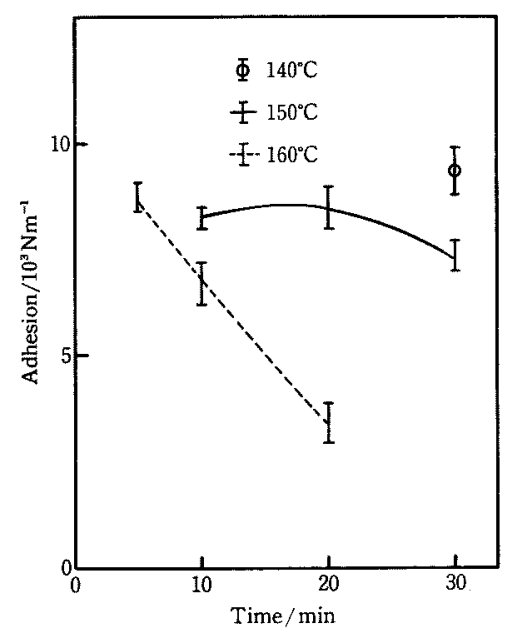

Fig. 10 Effect of cure time and temperature on adhesion of NR compounds with CBS and cobalt stearate.

加ゴムの接着力は加硫温度により著しく影響され，150 酸までと $160^{\circ} \mathrm{C}$ に㧍ける接着力は全く異なっていること がわかった. ヨ゙ムの架橋は, 加硫促進剤の種類, 加硫温 度等によりモノスルフィド, ジスルフィド，ポリスルフ イト架橋を生じることが知られている。 そこでナフテン 酸コバルトを添加した系の加硫温度による架橋形態に及 ぼす影響を調べた. CBS 配合ゴムのナフテン酸コバル ト未添加のときは, Fig. 13 に示したように140Cにて30

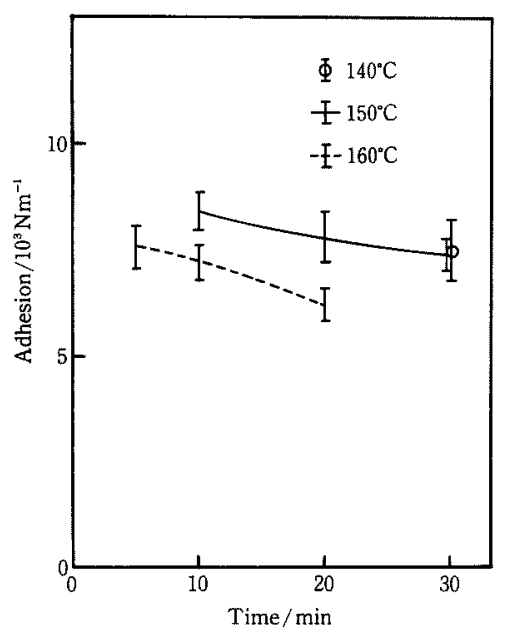

Fig. 11 Effect of cure time and temperature on adhesion of NR compounds with MBT and cobalt stearate.

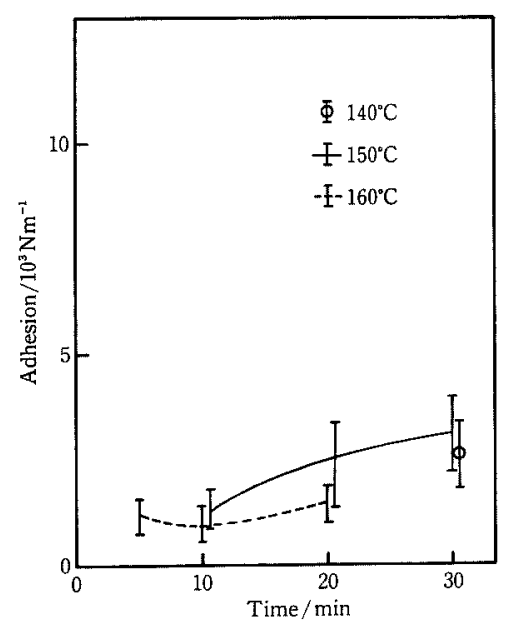

Figl 12 Effect of cure time and temperature on adhesion of NR compounds with ZnMDC and cobalt stearate.

分間の加硫では全網目鎖濃度 $1.34 \times 10^{-3} \mathrm{~mol} / \mathrm{cm}^{3}$ でその うちポリスルフィドが $75 \%$ ，ジスルフィドが $24 \%$ を占め ている.また，160年で20分間の過加硫の状態下では全網 目鎖数汢モノスルフィド架橋が増加した分だけ僅かに増 加しており，その差は小さい，一方，ナフテン酸コバル

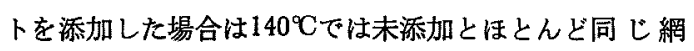
目鎖濃度であった。しかし，接着力が消失する $160{ }^{\circ} \mathrm{C}$ 加 硫ではポリスルフィド架橋が大きく減少し，モノスルフ 


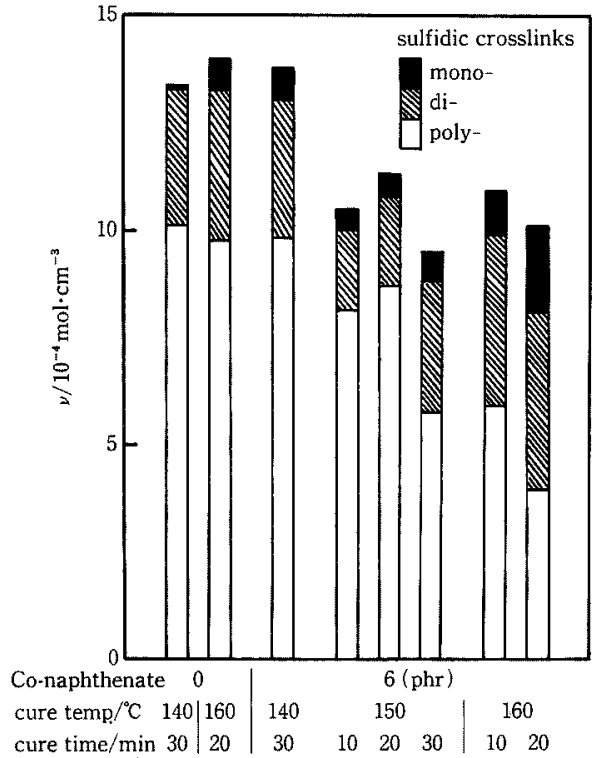

Fig. 13 Effect of adding cobalt naphthenate on cross link densities of NR compounds accelerated with CBS.

イドが増加している. ナフテン酸コバルトを末添加の場 合と比べると高温における硫黄の形態変化が顕著であっ た. ステアリン酸コバルトを添加した CBS 配合ゴムの 場合には，Fig. 14 に示したよ5に全網目鑽濃度は更に 減少し温度が高く時間が長いほどポリスルフィドの減少 が著しかった.これらの結果は加硫曲線から得たトルク 値の傾向と一致している.Fig. 15 は MBT 配合ゴムの 網目鎖漂度を示した. CBS に比ベポリスルフィド架 橋 数は少ないがナフテン酸コバルトを添加すると増加し， 更にモノスルフィド架橋も増して全網目鎖濃度は増加し ている. またステアリン酸コバルト添加の場合す $160{ }^{\circ} \mathrm{C}$ で20分間加硫によりモノスルフィド架橋が著しく増加し た. ZnMDC 配合ゴムは Fig. 16 に示したように，モ， スルフィドとジスルフィド架橋が多く, 高温ではジスル フィドとポリスルフィド架橋が著しく減少して全網目鎖 濃度は低下した，コバルト塩添加により，ZnMDC は反 态して不活性となり僅かの架橋しか形成しないが，ポリ スルフィド架橋の割合は約 $60 \%$ を占め高温では $40 \%$ 前後 に減少した.このよ5にナフテン酸コバルトの添加は高 温でポリスルフィド架橋の減少とモノスルフィド架橋の 増加を促進し，加硫促進風の種類によりその速度が異な ることがわかった．黄銅の接着にはポリスルフィド架橋

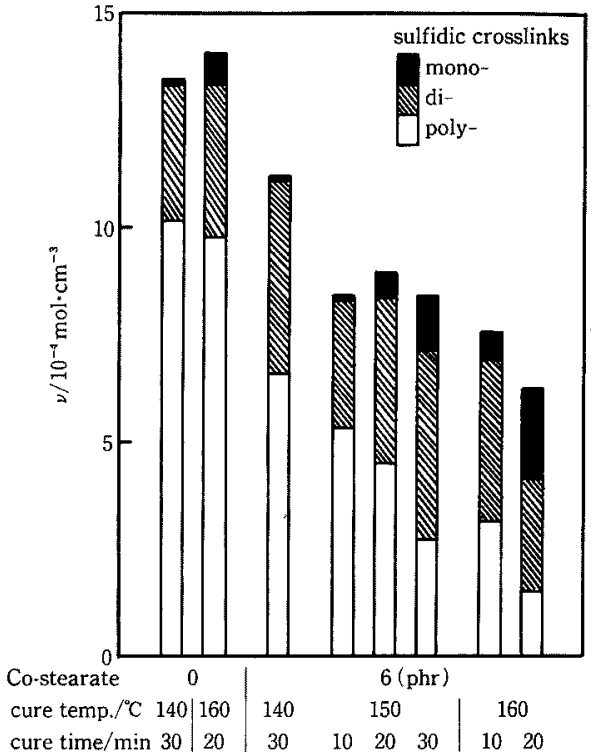

Fig. 14 Effect of adding cobalt stearate on cross link densities of NR compounds accelerated with CBS.

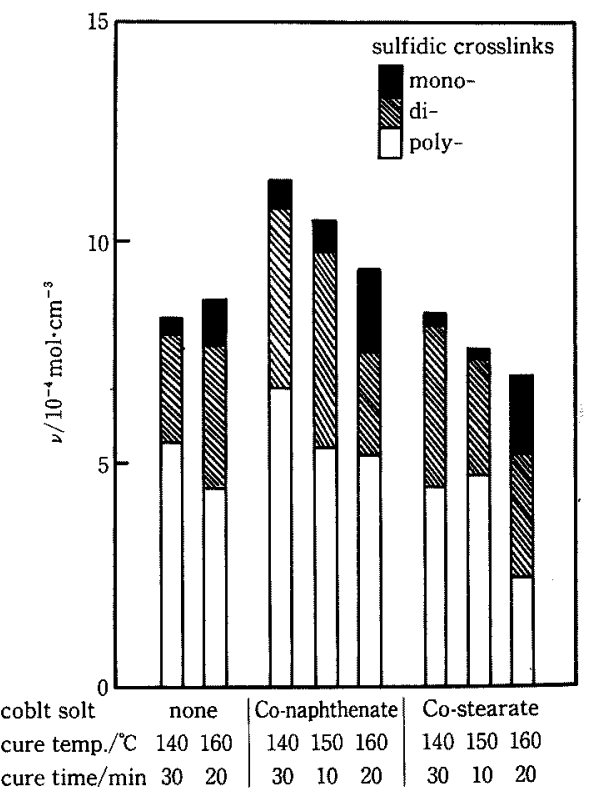

Fig. 15 Effect of adding cobalt salts on crosslink densities of NR compounds accelerated with MBT. 


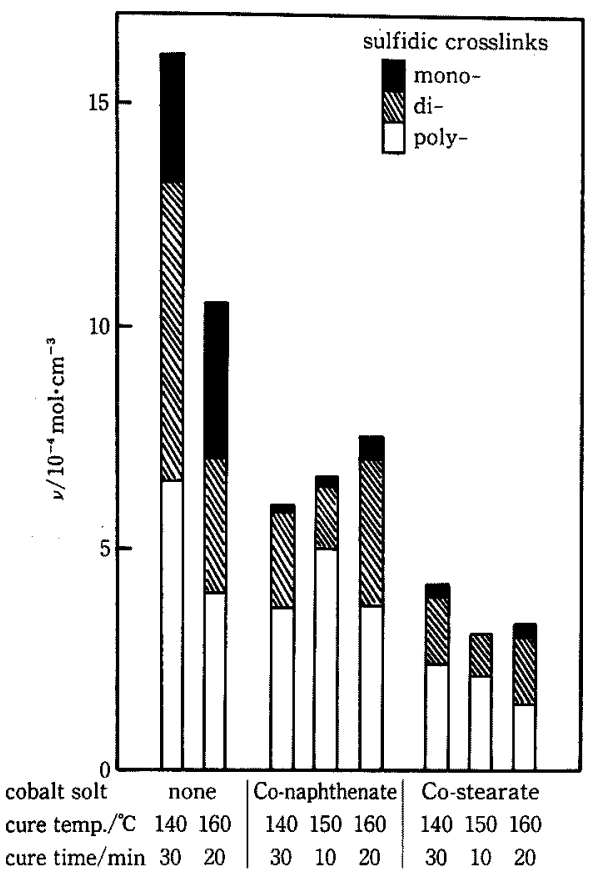

Fig. 16 Effect of adding cobalts on crosslink densities of NR compounds accelerated with ZnMDC.

が必要とされ ${ }^{16)}$, Ooijら ${ }^{172}$ は黄銅の接着研究で加硫時間 ととむにポリスルフィド架橋がかなり減少し, それと同 時にモノスルフィド架橋が増加することをみいたしてい る. しかしこの結果と接着力低下との関連は不明である としている.

すでに述べたようにナフテン酸コバルトを添加したゴ ムの CBS や MBT を用いた高温加硫では，ゴムと亜鉛 はいったん結合するが時間がたつとともに再び結合が開 裂して界面はく離してきた. 前報10〉で示したよらに, 強 い接着力を与えた亜鉛接着面の EPMA による表面分析 ではコバルトと硫黄が検出されたが，高温加硫により接 着不良となった亜鉛面上では硫黄が減少しコバルトはみ いだされなかった. また DPG 加硫による接着不良の亜 鉛表面には，これらの元素は検出されず，接着は硫黄と コバルトが亜鉛面へ移行して生ずると考えられる. Fig. 17 は $150^{\circ} \mathrm{C}$ にて30分間加硫した CBS 配合ゴムの良好な 接着を与えた亜鉛面と, $160^{\circ} \mathrm{C}$ にて 30 分間加硫して 接 着 不良となった亜鉛面の ESCA 分析による $\mathrm{S}_{2 p}$ スペクト ルを示した. 束縛エネルギー $160 \mathrm{eV}$ から $165 \mathrm{eV}$ のシャ ープなピークは $\mathrm{ZnS} と \mathrm{~S}$ の重なったものであり, 169 $\mathrm{eV}$ のプロードなピークは $\mathrm{SO}_{4}{ }^{2-}$ によるものである，接 着良好な面上には硫黄は硫化亜鉛, 遊離硫黄とともに硫

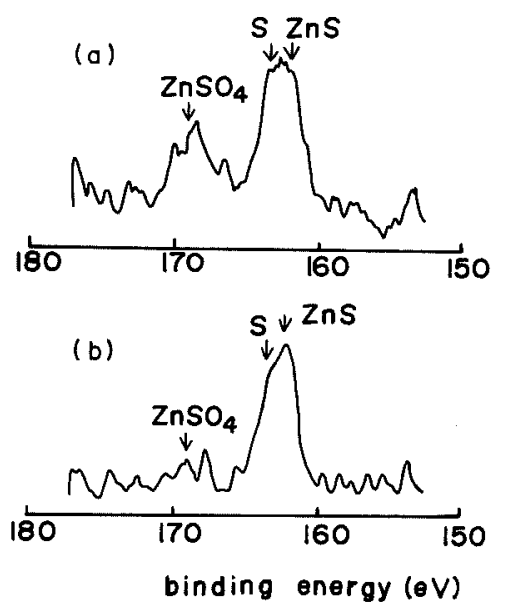

Fig. $17 \mathrm{~S}_{2 \mathrm{D}}$ photo lines on the interface of zinc plates adhere to rubber by curing at $150^{\circ} \mathrm{C}$ for $30 \mathrm{~min}$. (a) and at $160^{\circ} \mathrm{C}$ for $30 \mathrm{~min}$. (b).

酸亜鉛として存在し, 西鉛面は $\mathrm{ZnO}: \mathrm{ZnS}: \mathrm{ZnSO}_{4}=$ $62: 23: 15$ 割合の 3 成分から構成され，一方接着不良 となった面は $\mathrm{ZnO}: \mathrm{ZnS}: \mathrm{ZnSO}_{4}=55: 45: 0$ となり, 硫化重鉛は増加し硫酸要鉛は痕跡状態にまで減少した。 添加したナフテン酸コバルトは強い酸化触媒作用をもつ ので，ゴム中の遊離硫黄を酸化して硫酸要鉛を形成し， 高温では生じた硫酸鉛が時間とともに分解して，接着力 を低下させると同時に劣化を促進させると考えられる。 黄銅の接着面では硫酸要鉛の生成は報告されていな $W^{18)}$. これは亜鉛に特有の反応であるのか, 又は黄銅面 では生成量が少なくて検出できないのか，いずれかのた めであろ 5 .

$$
\text { ま と め }
$$

ナフテン酸コバルト又はステアリン酸コバルトを添加 したNR と亜鉛との接着における加硫促進㶡の影響を， 加硫挙動や架橋形態と接着強度の関連を検討し, 亜鉛板 表面の生成物を ESCA で分析した，その結果

1) チアゾール系とスルフェンアミド系促進剤の NR 加硫は，コバルト塩添加により加硫速度，最高トルク值 はほとんど変らす促進效果に及ぼす影響は小さい. チウ ラム系とジチオカルバミン酸塩系促進剂はコバルト塩と 反応して促進作用を消失する．しかし配合硫黄量が増す と過剩のコバルト塩による弱い加硫促進効果により加硫 速度は速くなり最高トルク值も増大した.

2） $\mathrm{MBT}$ 配合加硫の接着力は $150^{\circ} \mathrm{C}$ 以下で最大強度 を与えゴム層破壊であった. $160^{\circ} \mathrm{C}$ 以上では時間ととも 
に接着力は著しく低下した. 高温での接着力の低下は MBT よりむCBS が急激であった. チアゾール系の接 着強度は MBTS $>\mathrm{MBT}>\mathrm{ZnMBT}$ の順であった. $\mathrm{Zn}$ $\mathrm{MDC}$ は硫黄量が增すと充分に大きい接着力を与えた。 DPG 配合ゴムは接着せず界面はく離であった.

3）十フテン酸コバルト及びステアリン酸コバルトの 添加は，加硫温度 $160^{\circ} \mathrm{C}$ でポリスルフィド架橋数の減少 とモノスルフィド架橋の増加を促進した.

4）接着良好な要鉛表面には硫黄は硫化垔鉛，遊離硫 黄，硫酸要鉛として存在しており，高温で接着不良にな った重鉛面上には硫化亜鉛と遊離硫黄しか見出されなか った.

試料の ESCA 測定について御協力いただいたトクセ ン工業(㑣に感謝し，本研究に当たり(財)旭硝子工業技術奖 励会の助成を受けたことを感謝する。

本研究は日本ゴム協会第49回通常総会研究発表会で発 表した.

$$
\text { 文献 }
$$

1) Maesella, A., Debruyne, E.: Rubber Chem. Technol., 42, 613 (1969).

2) Wagner, M. P., Derringer, G. C.: Rubber Chem. Technol., 45, 1144 (1972).

3) Albrecht, K. D.: Rubber Chem. Technol., 46, 981
(1973).

4) Ulbrich, K. H., Backhaus, W.: Kautsch. Gummi, Kunststoffe, 27, 269 (1974); ibid. 27, 371 (1974).

5) Carpenter, G. T.: Rubber Chem. Technol., 51, 788 (1978).

6) Hicks, A. E., Chirico, V. E., Ulmer, J. D.: Rubber Chem. Technol., 45, 26 (1972).

7) Hicks, A. E., Lyon, F.: Adh. Age 21, (1969).

8) van Ooij, W. J.: Rubber Chem. Technol., 52, 605 (1979).

9) Fredenhagen, H.: Kautsch. Gummi, Kunststoffe 21, 437 (1968).

10）芦田道夫，福本隆洋，渡辺禎三：日ゴム協誌， 50, 807(1977).

11）芦田道夫，大野俊輔，菅 智史：日ゴム協誌， 53, 738(1980).

12) JIS, K6202 K6210

13) Rutz, G.: Plaste u. Kautschuk, 24, 705 (1977).

14) Campbell, D. S.:Rubber Chem. Technol., 43, 210 (1970).

15）古川淳三，小谷俤三，山下晋三，宮原俊夫： 日ゴム協誌，34，162(1961).

16) Weening, W. E.:Kautsch. Gummi. Kunststoffe, 31, 227 (1978).

17) van Ooij, W. J. Weening, W. E. Murray, P. F.: Rubber Chem. Technol., 54, 227 (1981).

18) van Ooij, W. J. Rubber Chem. Technol., 51, 52 (1978).

\section{STUDIES ON BONDING RUBBER TO METALLIC ZINC (III). THE EFECT OF ACCELERATORS ON ADHESION OF NR WITH COBALT SALTS TO ZINC PLATE.}

\section{Michio ASHIDA, Masaya NAKATANI, Yoshitaka TAKEMOTO and Makio GOTO (Department of Industrial Chemistry, Faculty of Engineering, kobe University, Rokkodai, Nada-ku, kobe 657 Japan)}

Vulcanization and adhesion to zinc plate of NR compounds with cobalt naphthenate or cobalt stearate was studied with many accelerators. NR Compounds with the cobalt salts were vulcanized similar to those without the salts by CBS, MBT, and other thiazole accelerators. The vulcanized rubber compounds produced a high adhesive strength to zinc plate. Addition of cobalt naphthenate to NR compounds gave higher adhesion than that of cobalt stearate. In the presence of cobalt naphthenate, polysulfidic crosslinks reduced with the curing time at $160^{\circ} \mathrm{C}$ and monosulfidic ones increased reversely, and adhesion strength decreased promptly at the temperture. The ultra-accelerators such as ZnMDC, TMTD, and NaMDC reacted with the cobalt salts under formation of a complex which was inactive to cure and the remainder of the cobalt naphthenate acted as a weak promotor for crosslinking. NR compounds accelerated with DPG did not adhere to zinc plate. It was found by ESCA that zinc surface of good adhesion was composed of zinc oxide, zinc sulfide, and zinc sulfate and the surface of poor adhesion was composed of zinc oxide and zinc sulfide. 